\title{
Machado de Assis, Funcionário Público
}

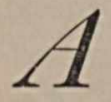

29 de setembro de 1908, com a morte de MACHADO DE Assis, perdeu o Brasil seu maior ficcionista e um dos mais primorosos mestres da língua portuguêsa.

Não constitui objeto de nossa homenagem louvar-1he aqui as qualidades artísticas: a clareza sintética cia exposição, a sobriedade do processo descritivo e a singeleza da técnica. Não vemos o autor do Braz Cubas, pintando a sociedade burguesa do século passado, com os fidalgos de D. Jỗo vi a discutirem, " de cabeleira e rabicho, casaca de seda e espadim", os despotismos de BoNAPARTE. Não nos ocupa o finíssimo criador de DOM CASMURRo, onde a concisa narração do primeiro beijo da astuta CAPITU, nos lábios de BENTINHo, é uma das mais finas jóias da literatura nacional, verdadeira obra-prima de concisão e graça.

Também não the vamos estudar a singularidade da ironia que, para Alcides MAIA, constitui a feição original do espírito crítico de MACHADO DE ASSIS, filósofo cético, mas benigno e indulgente, brincando constantemente com a própria melancolia, ao caracterizar os personagens, como em EsAú e JACó, onde vamos encontrat - NóBREgA velhaco pedindo esmolas para as almas, e metendo furtivamente na algibeira uma cédula de dois mil réis, dizendo com os seus botões que êle também possui uma alma como os outros. .

Nem queremos aqui realçar as elegâncias do estilo e engenhoso jôgo dos improvisos do luminoso artista e penetrante psicólogo da sociedade carioca em que viveu, caracterizada em QuINCAS BorBA, como ninguém o fizera antes, e de cujas páginas nitentes ressalta a índole pacífica e a lhaneza hospitaleira de nosso povo.

Lembramos, aqui, tão-sòmente aquêle MACHADo DE Assis que, no dizer de MonteIRo LoBato, "compreende bem cedo que, no Brasil, só como funcionário público teria o sossêgo da ausência de cuidados materiais, propício à realização do seu sonho instintivo 
- perpetuar-se sob a forma de um nome". Sonho êsse que se realizou graças à cautela desconfiada com que soube viver no meio carioca, com stıa extrema superioridade aliada à extrema sensibilidade de um orgulho sem licença de manifestar-se, em vista do tom da pele e do "cargo incolor" que ocupava na administração.

Em 1867, começou MACHADO DE Assis sua carreira no servico público, aos vinte e oito anos de idade, como ajudante de diretor do "Diário Oficial". E cinco anos mais tarde, era nomeado membro da Comissão do Dicionário Marítimo Brasileiro, passando, em 1873, a primeiro oficial da Secretaria do Ministério da Agricultura, onde, como funcionário de boa classe, se estabilizou, conquistando um nível de vida modesto, mas digno. $E$ isso, talvez, muito tenha influído no desenvolvimento do artista, pois - nos diz R. MAGALHÃES JR. -- "o que, aparentemente poderia afigurar-se um triste e inglório destino para tão alto escritor deve ter sido uma salvação, permitindo-1he que se aplicasse às letras, sem clesvio de suas faculdades intelectuais para outros campos, para as profissões ou labôres aproximados".

Não the foi, porém, êsse trabalho uma sinecura. Informa-nos Lúcia Miguel Pereira que - "cheio de escrúpulos e cuidados, c autor do Braz Cubas nunca escrevia uma informação diretamente no processo; fazia antes um rascunho, emendava-o, polia-o, passava-o a limpo, cuidadosamente, como se se tratasse de obras literária”. Conta-se até que, certa vez, um companheiro de trabalho o viu recomeçar nove vêzes a redação de um despacho, "quando, já diretor de Contabilidade, deveria estar mais que senhor das fórmulas de praxe". Que belíssimo exemplo de sinceridade e respeito para consigo mesmo, ainda no desempenho de suas tarefas de rotina como burocrata! . . .

É que seu espírito minucioso, cheio de escrúpulos, objetivava a perfeição em tudo que fazia.

O criterioso funcionário não envergonhava o contista mais perfeito de forma e mais requintado de idéias; pelo contrário, equilibravam-se na mesma balança o funcionário e o artista, o mestre do romance perfeito e o burocrata, o servidor exemplar, zeloso do catgo e fiel auxiliar, a quem se encomendavam tarefas importantes que logo se viam executadas com dedicação, inteligência e capacidade. 
Na Secretaria da Agricultura, estava MACHADo DE Assis constantemente intimado a dar parecer sôbre a execução das leis relativas à situação dos escravos e a dirimir questões referentes às matrículas dos cativos, pecúlios, educação e guarda de menores. E sempre escrupulosamente, como oficial de gabinete, redigia MACHADO DE Assis os avisos ministeriais, endereçados aos Presidentes das Províncias, dirimindo dúvidas, destrinxando o emaranhado dos textos legais, oferecendo normas e decisões para solução dos casos. que chegavam à mesa dos diferentes ministros a quem serviu.

Amante da liberdade, MACHADO DE Assis mostrou-se sempre, nos seus pareceres, um defensor dos interêsses dos escravos, cujos dramas e misérias pôde observar diretamente do seu pôsto.

É, porém, no Ministério da Viação e Obras Públicas, que MACHADO entra de licença para terminar seus dias, depois de ter servido durante trinta e cinco anos, com invulgar dedicação e competência, aos governos do Império e da República.

Se em sua obra nos deu o gracioso e elegante aticismo dos greg̉os, em sua vida funcional, nos deu o modêlo do servidor exem. plar. Se é seu nome glória das letras nacionais, foi sua vida, na administração, honta e ǵlória para o serviço público brasileiro. 